\title{
Searching for the Irish and Irish Studies in Australia ${ }^{1}$
}

\author{
Elizabeth Malcolm \\ University of Melbourne, Australia
}

Copyright (c) 2019 by Elizabeth Malcolm. This text may be archived and redistributed both in electronic form and in hard copy, provided that the author and journal are properly cited and no fee is charged for access.

\section{The Irish in Australia}

The Irish-Australian story is different in important respects from the Irish story in other parts of the diaspora. Therefore, before embarking upon any discussion of the writing or teaching of Irish Studies, it is important for readers to appreciate some of the main characteristics of the Irish experience in Australia.

Between 1800 and 2000, many more people left Ireland for the United States or Britain than for Australia. Unlike these older nations, Australia was a new settler society on the far side of the world. Its attractions were limited and travel there was expensive. Six British colonies had been established across the continent between the 1780s and the 1850s and, in 1901, these joined together in a federation to form the Commonwealth of Australia, a British dominion, which in that year had a white population of only 3.8 million. It has been estimated that Irish immigrants and their Australian-born offspring constituted around onequarter of this population. In other words, the Irish formed a larger proportion of the general population in Australia than in probably any other diaspora country. They were a substantial ethnic minority, second only in numbers to those of English birth and descent (Price).

Some of the Australian colonies also received Irish immigrants of a type not generally found elsewhere in the diaspora: these were convicts. New South Wales (NSW), with its capital city Sydney, was originally established by the British in 1788 as a penal settlement, intended as a place of punishment for those convicted of crimes in British and Irish courts. By 1868, when transportation finally ended, almost 50,000 Irish-born convicts had been shipped to Australia (O'Farrell, The Irish 22-53). What scholars call "forced migration" is therefore a distinctive chapter in the story of the Irish in Australia. Australia's convict origins were for many years a source of shame to its later inhabitants, including many Irish Australians, some of whom chose to believe that Irish convicts were mainly "exiles", that is political prisoners (Kiernan). This is not in fact true: most had been convicted of theft. Towards the end of the $20^{\text {th }}$ century, however, attitudes began to change, with the convicts' major contribution to the establishment of colonial Australia being finally acknowledged. Now convict ancestry is widely valued: to have an Irish convict ancestor in the family tree - even one transported for larceny - is a source of considerable pride ("Not Just Ned").

During the 1830s, the British government introduced another novel factor when it began subsidising the cost of the long journey to Australia in an effort to boost the size of the free settler population. The Irish took full advantage of the offer of assisted travel (Reid, Farewell). Since the authorities were keen to provide wives for the largely male population, 
substantial numbers of these subsidised immigrants were young single women (Hall and Malcolm). The Great Famine of the late 1840s did not lead to a major upsurge in Irish immigration to Australia, as it did to nearer and cheaper destinations like Britain and North America (Reid, "Person"). This paucity of destitute Famine refugees meant that the Australian Irish community did not share the traumatic Famine memories that were to be so influential amongst the Irish in the United States (Donnelly Jr). But, there was a marked increase in Irish arrivals from the 1850s, many of these immigrants being attracted by the discovery of gold in parts of eastern Australia. They came in hopes of achieving instant wealth - a dream that very few realised (McConville 29-30).

Australia thus gained Irish-born inhabitants initially by forced convict transportation. Later the offer of assisted passages attracted numerous free immigrants, especially women, while, during the 1850 s and 1860 s at least, the lure of gold was important. Chain migration quickly developed as successful settlers wrote letters encouraging friends and relatives to join them. Many of these immigrants came from counties in Munster and along the Ulster border (Fitzpatrick 6-19). But, when assisted immigration schemes began to be curtailed from the 1880 s, Irish arrivals declined, although small numbers did continue to make the long journey "down under" throughout the $20^{\text {th }}$ century. More recently, the collapse of the Irish economy in 2008 saw an upsurge in immigration during the following decade, with young Irish people heading to Australia in search of jobs (Breen).

Irish immigrants had scattered fairly widely across the vast continent during the $19^{\text {th }}$ century. They did not necessarily become urban dwellers, as did so many of those who immigrated to the United States and Britain. The largest groups congregated in eastern Australia: in the colonies - later states - of NSW, Victoria and Queensland. Like Irish immigrants to other destinations, those arriving between the 1830s and the 1890 s were mostly unmarried young women and men from rural backgrounds. Although there were middle-class immigrants, the majority of the Irish were working class and unskilled. As for their religious affiliations, while there were significant numbers of Protestants, especially from Ulster, at least three-quarters of the Irish were Catholics (McConville 30-39).

In $19^{\text {th }}$-century Australia, the Catholic Irish found themselves living in colonies alongside white neighbours who were mainly of Protestant British birth or parentage. Before the late 1940s and the arrival of large numbers of Catholic immigrants from war-torn southern and eastern Europe, the vast majority of Catholics in Australia came from Irish backgrounds. The Catholic Church too, for nearly 100 years up until the middle of the $20^{\text {th }}$ century, was dominated by Irish-born and -trained clergy. Thus, as in Ireland itself, a strong link was forged in Australia between Irishness and Catholicism. With the assistance of the church, Irish-Australian Catholics succeeded in maintaining their own distinctive identity. Bishops built schools, hospitals and welfare institutions in their dioceses. They established devotional and cultural societies for the laity and organised specifically Catholic festivals, turning parish churches into social hubs. In some of the main cities the church owned newspapers that promoted Catholic interests, while priests showed a marked willingness to speak out on political issues. As in Ireland, the church in Australia was not shy in asserting what it considered to be Catholic rights. From the 1870s, it campaigned especially in favour of state funding for church schools (O'Farrell, The Catholic Church 194-297). But, unlike Ireland, Australia was a majority Protestant country and many Protestants were quick to resent Catholic claims and, in some instances, to reject them. As a consequence, religious tensions simmered constantly, occasionally flaring into violent confrontations (Kildea).

During the late $19^{\text {th }}$ century, working-class Irish Australians became very active in the labour movement across the country. Mass trade unions for unskilled and semi-skilled workers began appearing during the 1880s and labour parties during the 1890s, with a federal Australian Labor Party (ALP) being established in 1900. Today the ALP is still one of the two 
largest political parties in the country. Up until the 1950s, and even beyond, Irish Australians were a powerful force within the party as the Catholic Church had encouraged its flock to vote ALP. The church was certainly alarmed by socialist and later communist influence in the party, which it actively sought to curb, but essentially the bishops saw the ALP as better representing Catholic working-class interests than other more conservative parties that were dominated by the Protestant middle class and often exhibited a marked anti-Catholic bias (Malcolm and Hall, "Catholic Irish").

So, in Australia, the Irish-led Catholic Church was very politically active and influential. But, not until the early 1960s did a federal centre-right coalition government, led by the Liberal Party, finally agree to provide state aid to Catholic schools. By then, however, the increasingly prosperous Irish-Australian community was drifting away from its labour roots more towards the conservative side of politics - though the Liberal Party did not see its first Catholic prime minister until 2013.

Today, Australia's Catholic voters are an ethnically diverse group and they are as likely to support centre-right as centre-left parties. Yet, throughout most of the $20^{\text {th }}$ century, politics had divided along markedly ethnic and sectarian lines, with Catholic Irish Australians overwhelmingly supporting the ALP, while many Protestant Anglo-Australians supported various conservative parties (Warhurst).

\section{The Irish in Australian Studies}

The leading historian of Irish Australia, the late Professor Patrick O'Farrell (1933-2003), claimed in his ground-breaking 1986 book, The Irish in Australia, that the "distinctive Australian identity ... was born in Irishness protesting against the extremes of Englishness". According to O'Farrell, it was the existence of a large "insubordinate" Catholic Irish minority, always ready to challenge Protestant English authority, that helped foster in colonial Australia "a general atmosphere in which exclusion, discrimination and rigid hierarchies became increasingly less possible to sustain" (5-21). O'Farrell believed that the Catholic Irish had prevented Australia from becoming a mere carbon-copy of England. They had helped promote a more egalitarian, open and tolerant society, which even the Anglo-Australian majority eventually came to embrace. However, these sweeping claims have proved controversial and they are by no means universally accepted.

Given the sheer size of the Catholic Irish-Australian community, as well as its political and religious activism, one might be forgiven for assuming that scholars working in the field of Australian Studies would have devoted a good deal of attention to the Irish. This, however, is not the case. The Irish have essentially been side-lined in Australian scholarship. This is true in the field of history, as well as in literary and cultural studies. There is certainly a significant specialist literature dealing with the Irish, largely written by Irish Australians themselves, but in mainstream Australian Studies the Irish figure only fleetingly, if at all. And when they do appear, they are often presented in a far from flattering light.

The reasons why the Irish were ignored in the past by Australian scholars, and continue to be marginalised today, are multiple. In the past, Australian academics were often of British birth or descent and many spent time in Britain, frequently taking their graduate degrees from British universities. They were thus knowledgeable about Britain and anglophile in their attitudes. Few ever crossed the Irish Sea to spend much time in Ireland or bothered to acquaint themselves in any detail with Irish history and culture. Instead, they tended to see the Irish through British eyes - and, of course, the British have a long history of anti-Irish attitudes. As a result, evidence of anti-Irish sentiment in past and recent Australian scholarship is not hard to find (Malcolm, “After O'Farrell”). 
One of the best-known and most controversial Australian historians of the last 50 years has been Professor Geoffrey Blainey (1930-). In a history of the state of Victoria, first published in 1984 and reissued in 2006, Blainey included three entries in the index under the heading "Irish". These were "sectarianism", "Catholic church" and "negative nationalism". Readers were informed that sectarianism involved "Ireland versus Ireland", as well as "Ireland versus the Rest": meaning Irish Catholics in conflict with Irish Protestants as well as with British Protestants. Either way, religious division was portrayed by Blainey as something the Irish had introduced and fostered in Australia. The chapter on religion was entitled "Sunshine and Moonshine", for, after treating the "sunshine" of religion, Blainey moved on to the "moonshine" of alcohol. Here too the Irish figured prominently, being characterised as "strong drinkers". In addition to promoting sectarianism and alcoholism in Australia, the other main achievement of the Irish, according to Blainey, was to introduce what he called "negative nationalism". This "noisy" creed was brought "ready-made" to Australia by the Irish, its chief characteristic being a bitter "dislike of England". Blainey contrasted this with "positive nationalism", which was "home-grown" and expressed a healthy love for Australia (117, 123, 134). O'Farrell's claim that the Irish had played a crucial positive role in the development of Australian nationalism was ignored. Instead, Blainey portrayed the Irish as a troublesome, divisive group who seemed bent upon sowing discord in an otherwise harmonious settler society.

As well as expressions of open hostility, such as those evident in the writings of anglophile historians like Blainey, Australian Studies have also exhibited a marked tendency to ignore the Irish by subsuming them into larger ethnic or religious categories. They are treated as "British" or as "Catholic"; more recently, the terms "Anglo-Celtic" and "white" have become popular in both academic and popular discourse (Dixson; Hage). To outsiders, it must seem odd that in Australia the Irish are often classed as "British". After all, Catholic Irish people do not usually consider themselves British and nor do most British people think of the Irish as British either. Australian usage of the category "British" to include the Catholic Irish is unusual, and it has its roots in an insecure colonial mindset. The British-born rulers of early $19^{\text {th }}$-century Australia perceived the large Irish community - whether convict or free as a potential threat. The Irish, in the eyes of Protestant British officials, were a lawless and rebellious people, sunk in Catholic "superstition". One way of controlling them was to attempt to assimilate them into British-dominated colonial society by effacing their difference. Referring to them as "British" and denying their Irishness fitted this strategy. Another tactic employed was the creation of an English-dominated Catholic Church in Australia. It was hoped that a church staffed by loyal English-born clergy would help anglicise the Irish. Initially, during the early convict period, priests were barred from the country altogether, but, when they were finally admitted from the 1820 s, preference was given to English over Irish clergy, despite the fact that both the convict and free Catholic communities were overwhelmingly Irish. Eventually, though, the Irish did gain firm control of the Australian Catholic Church, but only after decades of effort (O'Farrell, The Catholic Church 40-137).

Up to the present day, Australian historians have continued the colonial practice of treating the Irish as "British" or "Catholic" and attempting to ignore their distinctive ethnic identity. For example, the massive 1,200-page, two-volume Cambridge History of Australia, published in 2013, does not include O'Farrell's 1986 seminal history in its 44 pages of bibliography, only citing one of his earlier works on the history of the Australian Catholic Church. In the index to the first volume, there are just eight entries on the Irish; in the index to the second volume, there are no entries on the Irish at all. These volumes continued to deal with the Irish in the same way that much mainstream Australian historiography had dealt with them prior to O'Farrell's 1986 book: that is the Irish were relegated to the category "Catholic" 
and discussed in the context of religious history. And this treatment was frequently critical, with Irish Catholics invariably linked to sectarian conflict (Bashford \& Macintyre, vol. 1, 207-209, 417-418, 430-431).

In a 1978 lecture, O'Farrell had pointed out that, following the substantial waves of immigration to Australia since 1945 - first from southern and eastern Europe and later from Asia - the Irish were now not regarded as an "ethnic minority". He argued, however, that they should be viewed in ethnic terms, for although he believed that they had ultimately been, as he put it, 'incorporated' into an Australian identity, this process had been a very protracted one, stretching across nearly 150 years. Moreover, the process had generated much bitter controversy and sometimes violent conflict, and it had proved fundamental to the emergence of Australia's distinctive identity (17). As for religion, although O'Farrell had published extensively on the Catholic Church in Australia, towards the end of his life he came to stress that sectarianism was not primarily about religion - it was in reality about power. As he wrote in an unpublished study in 2002: "At the heart of the sectarian terrain were issues of power and control, what beliefs and interests should rule, and who should rule" (13). Subsuming the Irish into categories like 'British' or 'Catholic' was part of a process of dis-empowerment that began during the colonial era and, strangely enough, persists even to the present day.

Much current writing in the field of Australian Studies focuses on issues of race, gender and colonialism. It is devoted to interrogating tensions between "black" Indigenous Australians and "white settlers" and between women and men and exposing the discriminatory white, male-dominated society that such tensions gave rise to. But this approach means that the ethnic diversity of colonial Australia's settler population is usually obscured. The Irish disappear into the category "whites" or "settlers" or "Anglo-Celts", while Irish women become just "women" and Irish men just 'men'. But ignoring ethnicity can have odd outcomes. For example, although Irish-born women made up nearly half of all the female convicts shipped to Australia, some influential feminist studies of transportation make virtually no mention of the Irish at all (Damousi).

A myth exists today in Australian Studies, and in the minds of many ordinary Australians, that the country was settled by the "British", amongst whom was a small but rather troublesome sectarian minority, the "Catholics". Thus have the ethnic Irish, both Catholic and Protestant, been largely banished from numerous works dealing with Australia's history and culture.

\section{Irish Studies in Australia}

Given this long history of ignoring or slighting the Irish as an ethnic minority, it is not surprising that Irish Studies have struggled in Australia. Irish Australians have certainly produced a substantial literature of their own about themselves. The first book entitled The Irish in Australia appeared in London in 1887, the work of a Catholic Irish-born journalist and later nationalist politician, J.F. Hogan, who had spent his childhood and youth in Australia. But, until recent decades, much of this literature has been self-serving. It has aimed essentially to celebrate the achievements of Irish-born immigrants and their offspring, nearly all of them men. Priests, nationalist heroes and outlaws have figured prominently in such works. The Young Ireland leaders, John Mitchel and William Smith O'Brien, transported in connection with the 1848 Rebellion, the bushranger Ned Kelly, executed for murder in 1880, and the Catholic archbishop of Melbourne, Daniel Mannix, a strong supporter of the 1916 Rising, have attracted dozens of admiring studies (Kiernan; Jones; Santamaria). These men are obviously important, yet much that has been written about them is superficial, uncritical and on occasion highly romanticised. 
History has been by far the most popular Irish Studies discipline in Australia, with literary and cultural studies following some distance behind. Literary scholarship tends, moreover, to be dominated by studies of Irish-born authors who wrote in Ireland, Britain or Europe, rather than by studies of Irish-Australian authors, even though there have been many notable Australian writers of Irish descent. In addition, leading Anglo-Irish writers, like Yeats, Synge, Wilde, Joyce, Shaw, Beckett and Heaney, are usually taught in school or university curricula as part of courses dealing with "English" or "British" literature, while Irish-Australian writers feature in courses on "Australian" literature. There are no specialist courses on Irish-Australian literature and few devoted purely to Irish literature either. Joyce's "Bloomsday" is, however, celebrated on 16 June each year in parts of Australia. In Melbourne, for example, since the 1990s a group of enthusiasts led by Frances Devlin-Glass has been organising readings and discussions of Joyce's work, as well as staging dramatized episodes from Ulysses (<bloomsdayinmelbourne.org.au〉).

Despite this focus on Irish writers, some of Australia's own earliest and, indeed, bestknown writers have been of Irish birth, parentage or descent $(A D B)$. The most significant convict poet, simply known as "Frank the Poet" (Francis MacNamara, c.1810-61), was Irishborn. He composed powerful verses about the hardships of convict life, many of which were set to music and became popular folk ballads. Charles Harpur (1813-68), generally recognised as Australia's first major poet, was the son of an Irish convict father. Later important $19^{\mathrm{th}}$ - and $20^{\text {th }}$-century poets included Irish-born Victor Daley (1858-1905), as well as Bernard O'Dowd (1866-1953), Christopher Brennan (1870-1932), R.D. FitzGerald (1902-87), James McAuley (1917-76) and Vincent Buckley (1925-88), all of whom were descendants of Irish convicts or free immigrants. Some wrote about their Irish family backgrounds and a handful visited Ireland. Buckley, for instance, lived in the country during the early 1980s and produced a book about his experiences (Buckley). Irish-Australian novelists and short story writers are also plentiful. A far from complete list would include: "Rolf Boldrewood" (T.A. Browne, 1826-1915); Joseph Furphy (1843-1912); Barbara Baynton (1857-1929); "Steele Rudd" (A.H. Davis, 1868-1935); "Henry Handel Richardson" (Ethel Richardson, 1870-1946); C.J. Dennis (1876-1938); Eleanor Dark (1901-85); and Christopher Koch (1932-2013).

More recently, Irish-Australian novelists Thomas Keneally (1935-), Peter Carey (1943-) and Richard Flanagan (1961-) have all been awarded the prestigious international Booker Prize. Keneally won in 1982; Carey won twice, first in 1988 and again in 2001; while Flanagan won in 2014. Keneally and Flanagan have both written about Ireland and their Irish ancestry, with Keneally producing a large account of the history of Ireland and of the Irish in Australia (Keneally). Carey's prize-winning 2001 novel was based on the life of the bushranger Ned Kelly, the son of an Irish convict father. In a 2014 interview, Carey acknowledged being inspired in part by the famous series of Kelly paintings done during the 1940s by the Irish-Australian artist, Sidney Nolan (Gleeson).

Biographies of some of these writers have been published, as well as critical studies of their works, but no scholar has investigated this large body of Irish-Australian literature spanning nearly two centuries - from the perspective of its Irishness. There has been no systematic attempt to determine how these writers as a group perceived their ethnic ancestry and the ways in which it shaped their output.

Some scholarly attention has, however, been paid to the impact of the Irish on Australian cinema, music, painting, language and popular culture, as well as their impact on politics (Malcolm and Hall, A New History of the Irish in Australia). Irish-Indigenous relations are just beginning to be explored (McGrath), while recently the imprint of Irish immigrants on the landscape has attracted interest (Proudfoot and Hall). And archaeologists have been investigating areas of Irish settlement, in Sydney and Melbourne particularly and also in parts of rural South Australia (Arthure). 
There is little doubt that the Troubles in Northern Ireland, beginning in the late 1960s and stretching across 30 years, sparked renewed interest about Ireland in Australia. A number of academics - historians in the main - began writing and teaching in the field of Irish Studies from the 1960s onwards. They attracted postgraduate students to undertake further research, while their efforts also led to the holding of regular conferences, which brought together Irish enthusiasts from around the country. The conferences in turn generated books of proceedings and eventually a journal of Irish Studies was also established. Both the conferences and the journal evolved to take in Australasia: that is New Zealand as well as Australia.

Patrick O'Farrell, the New Zealand-born son of Irish immigrant parents, began teaching Irish history at the University of NSW in Sydney during the late 1960s. At the same time he was publishing work on the history of the Catholic Church in Australia, before moving on during the 1970s and 1980s to write about Irish immigration and settlement. His 1986 book, The Irish in Australia, which was re-published in revised editions in 1993 and 2000 , is still considered, as mentioned, the standard work on the subject. O'Farrell also promoted postgraduate research on Irish and Irish-Australian history - the author of this article being one of his former students (Malcolm, "Obituary"). Carlow-born and Cambridgeeducated Oliver MacDonagh (1924-2002) held a position at Flinders University in Adelaide during the late 1960s, before in 1973-90 occupying a chair of history at the Australian National University in Canberra. MacDonagh made major contributions to Irish political and cultural history, as well as to Irish-Australian history (Dunne). In 1980 he also inaugurated an influential Irish Studies conference series that continues to this day. The $23^{\text {rd }}$ Australasian Irish Studies Conference was held at the University of Sydney in November 2018 (<isaanz.org >).

While O'Farrell in Sydney and MacDonagh in Canberra were leading promoters of Irish Studies from the 1960s into the 1990s, there were and are a number of other notable academic contributors to the history of the Irish in Australia in other parts of the country, as well as a handful overseas. Below is a list of some, although far from all, of these scholars.

- Richard Davis at the University of Tasmania in Hobart published on the Irish in Tasmania and especially on the Young Irelander, William Smith O'Brien, transported for his part in the 1848 Rebellion (Davis).

- $\quad$ Bob Reece at Murdoch University in Perth worked largely on Irish convict history (Reece) and, in 2001, established an Australian journal of Irish Studies. The journal moved to Melbourne in 2006 and became the Australasian Journal of Irish Studies. Published annually, volume 18 appeared in September 2018 (<isaanz.org>).

- $\quad$ Eric Richards at Flinders University in Adelaide focused on immigration, not only from Ireland but Scotland as well (Richards).

- Trevor McClaughlin at Macquarie University in Sydney pioneered study of the Irish Famine orphans: 4,100 teenage girls sent to Australia from Irish workhouses during 1848-50 (McClaughlin).

- Chris McConville at Victoria University in Melbourne investigated Irish patterns of settlement in Sydney and Melbourne, as well as writing a short history of the Irish in Australia (McConville).

- Dianne Hall, also at Victoria University, has published on the issues of gender and race, as well as on Irish-Australian rural settlement patterns (Hall, "white man").

- $\quad$ Philip Bull at La Trobe University in Melbourne has researched the land question in both Ireland and Australia (Bull).

- $\quad$ Mark Finnane at Griffith University in Brisbane has published major works on the history of mental health and policing in both Australia and Ireland (Finnane).

- Jeff Kildea at the University of NSW in Sydney has focused on sectarianism and also on IrishAustralian soldiers during the First World War (Kildea).

- Working at Trinity College, Dublin, since the 1970s, Australian-born David Fitzpatrick has been a leading historian of Irish immigration, not only to Australia but Britain as well (Fitzpatrick).

- $\quad$ And, at the University of Auckland in New Zealand, Australian-born Malcolm Campbell has been comparing the Irish experience in Australia with that in the United States (Campbell). 
Much important work has also been undertaken by independent scholars, pursing research outside universities. For example, Perry McIntyre and Liz Rushen have produced a series of books about Irish female immigration to Australia during the mid $19^{\text {th }}$ century (Rushen). In addition, in 2007 they established a publishing house in Sydney, Anchor Books Australia, that specialises in works about the Irish in Australia, as well as Australian history more generally.

Since the 1960s, the promotion of Irish Studies has relied heavily upon the efforts and enthusiasm of individuals, both inside and outside academe. The Australian experience is not unusual in this regard as, in many countries, the study of Ireland very much depends upon the efforts of small groups. But, a number of the university-based scholars listed above have now retired and, unfortunately, few have been replaced by people with similar expertise in Irish Studies (Malcolm, "10,000 Miles"). In response to this situation, efforts have been made since 2000 to secure the future of Irish Studies by the establishment of an Irish Studies Association of Australia and New Zealand (ISAANZ), while at some universities chairs have been created, largely funded by wealthy Irish-Australian families. The first chair of Irish Studies was established at the University of Melbourne in 2000. Held by Irish historian Elizabeth Malcolm until 2012, it is currently occupied by Rónán McDonald, whose field is modern Anglo-Irish literature. Previously, during 2010-15, he had held a chair of Irish Studies at the University of NSW in Sydney (Malcolm \& Bull). Since 1986, a programme of Celtic Studies has been taught at the University of Sydney, specialising in the Celtic languages and Medieval Studies, and a chair was added to this programme in 2008. Held first by the late Anders Ahlqvist (1945-2018), an early Irish language expert, the current professor is Jonathan Wooding, who, while specialising in medieval Irish and Welsh history, has also published on Irish-Australian topics (Wooding).

So, in Australia today, Irish history and literature are taught at certain universities, mostly in Sydney and Melbourne. But they are taught as single semester courses in general Bachelor of Arts degrees; they are not taught as part of a dedicated Irish Studies degree programme, as happens at some universities in the United States, Canada and Britain. The fact that Australia lacks even one Irish Studies programme further underlines how the major contributions made by the Irish to the country's history and culture have been marginalised.

Nonetheless, as in other parts of the diaspora, recent centenaries and commemorations have played a role in boosting public interest by reminding people of dramatic Irish events and how they impacted Australia. The Famine commemoration in the mid 1990s, the bicentenary of the 1798 Rebellion and the centenary of the 1916 Easter Rising - plus the upcoming centenary of the 1919-21 Irish War of Independence - have been key events, giving rise to conferences, books, television documentaries and monuments. There are now Famine memorials in both Sydney and Melbourne and Sydney's impressive existing 1798 memorial in Waverley cemetery at Bronte, created in 1898 to mark the centenary of the rebellion, has been restored (<irishfaminememorial.org>). In this context, tribute should be paid to successive Irish governments and Irish ambassadors to Australia, who have helped fund many of these commemorative ventures, as well as facilitating cultural organisations, like the Irish Language Association of Australia, established in 1992, which holds classes in a number of locations, as well as an annual winter school in Sydney (<gaeilgesanastrail.com>).

\section{Conclusion}

Irish Studies is very much a specialist interest in Australia, its survival dependent upon the commitment and hard work of individual scholars or small groups of enthusiasts - most of whom are of Irish descent. The wider world of Australian historical and cultural studies, especially within the universities, tends to ignore the Irish and thus underestimate and even misunderstand their contribution to the development of modern Australia. But scholarship 
evolves ceaselessly, often in unexpected directions, and so there are grounds for optimism that Irish Studies may yet join the mainstream and, in the future, find its insights and interpretations better appreciated by new and larger Australian audiences.

\section{Notes}

1 An earlier version of this paper was delivered at the Global Irish Diaspora $1^{\text {st }}$ International Congress, University College, Dublin, 15-19 August 2017.

\section{Works Cited}

Arthure, Susan. “An Irish Dig Down Under”. Archaeology Ireland 32.1 (2018): 21-25.

Bashford, Alison and Stuart Macintyre, eds. The Cambridge History of Australia. 2 vols. Cambridge: Cambridge University Press, 2013.

Blainey, Geoffrey. A History of Victoria. Rev. ed. Cambridge: Cambridge University Press, 2006.

Breen, Fidelma. "Emigration in the Age of Electronic Media: Personal Perspectives of Irish Migrants to Australia, 1969-2013". Ireland in the World: Comparative, Transnational and Personal Perspectives. Ed. Angela McCarthy. New York: Routledge, 2015. 198233.

Buckley, Vincent. Memory Ireland: Insights into the Contemporary Irish Condition. Melbourne: Penguin Books, 1985.

Bull, Philip. Land, Politics and Nationalism: A Study of the Irish Land Question. Dublin: Gill and Macmillan, 1996.

Campbell, Malcolm. Ireland's New Worlds: Immigrants, Politics and Society in the United States and Australia. Madison, WN: University of Wisconsin Press, 2008.

Damousi, Joy. Depraved and Disorderly: Female Convicts, Sexuality and Gender in Colonial Australia. Cambridge: Cambridge University Press, 1997.

Davis, Richard P. Revolutionary Imperialist: William Smith O'Brien, 1803-64. Sydney: Crossing Press, 1998.

Dixson, Miriam. The Imaginary Australian: Anglo-Celts and Identity, 1788 to the Present. Sydney: University of NSW Press, 1999.

Donnelly Jr, J.S. "The Construction of the Memory of the Famine in Ireland and the Irish Diaspora, 1850-1900". Eire-Ireland 31. 1-2 (1996): 26-61.

Dunne, Tom, ed. Looking Back: Living and Writing History. Oliver MacDonagh, 1924-2002. Dublin: Lilliput Press, 2008.

Finnane, Mark. "The Easter Rising in Australian History and Memory". Australasian Journal of Irish Studies 16 (2016): 30-46.

Fitzpatrick, David. Oceans of Consolation: Personal Accounts of Irish Migration to Australia. Cork: Cork University Press, 1994.

Gleeson, Sinead. "Peter Carey: Secrets in the Information Age". The Irish Times. 15 November 2014. https://www.irishtimes.com

Hage, Ghassan. White Nation: Fantasies of White Supremacy in a Multicultural Society. New York and London: Routledge, 1998.

Hall, Dianne. "Now him white man': Images of the Irish in Colonial Australia". History Australia 11. 2 (2014): 167-195. and Elizabeth Elizabeth. "Diaspora, Gender and the Irish". Australasian Journal of Irish Studies 8 (2008/9): 3-29.

Jones, Ian. Ned Kelly: A Short Life. New ed. Melbourne: Lothian Books, 2003.

Keneally, Thomas. The Great Shame: A Story of the Irish in the Old World and the New. Sydney: Random House, 1998. 
Kiernan, T.J. Irish Exiles in Australia. Melbourne: Burns and Oates, 1954.

Kildea, Jeff. Tearing the Fabric: Sectarianism in Australia, 1910-25. Sydney: Citadel Books, 2002.

McClaughlin, Trevor. Barefoot and Pregnant? Irish Famine Orphans in Australia. 2 vols. Melbourne: Genealogical Society of Victoria, 2002 (1991).

McConville, Chris. Croppies, Celts and Catholics: The Irish in Australia. Melbourne: Thomas Nelson, 1987.

McGrath, Ann. "Shamrock Aborigines: The Irish, the Aboriginal Australians and their Children”. Aboriginal History 34 (2010): 55-84.

Malcolm, Elizabeth. "10,000 Miles Away: Irish Studies Down Under". Ireland Beyond Boundaries: Mapping Irish Studies in the Twenty-First Century. Eds. Liam Harte and Yvonne Whelan. London: Pluto Press, 2007. 39-47.

. "After O'Farrell: Writing a New History of the Irish in Australia". Tinteán: The Australian Irish Heritage Network. 6 August 2017. https://tintean.org.au

. “Obituary: Patrick O'Farrell, 1933-2003”. History Australia 1. 2 (2004): 321-324.

and Philip Bull. "Irish Studies in Australia, 1980-2012". Australasian Journal of Irish Studies 13 (2013): 29-44.

and Diane Hall. "Catholic Irish Australia and the Labor Movement: Race in Australia and Nationalism in Ireland, 1880s-1920s". Frontiers of Labor: Comparative Histories of the United States and Australia. Eds. Greg Patmore and Shelton Stromquist. Urbana, Chicago and Springfield, Ill: University of Illinois Press, 2018. 149-167. . A New History of the Irish in Australia. Sydney: NewSouth Publishing, 2018.

O'Farrell, Patrick. The Catholic Church and Community in Australia: A History. Melbourne: Nelson, 1977.

- "Imagination's Stain: Historical Reflections on Sectarian Australia". Ed. Clare O'Farrell. 2002. http://www.patrickofarrell.com

. "The Irish and Australian History". Quadrant 22. 12 (1978): 17-21.

. The Irish in Australia. Sydney: University of NSW Press, 1986.

Price, C.A. "The Ethnic Character of the Australian Population". The Australian People: An Encyclopedia of the Nation, its People and their Origins. Ed. James Jupp. $2^{\text {nd }}$ ed. Cambridge: Cambridge University Press, 2001. 78-85.

Proudfoot, Lindsay and Dianne Hall. Imperial Spaces: Placing the Irish and Scots in Colonial Australia. Manchester: Manchester University Press, 2011.

Reece, Bob. The Origins of Irish Convict Transportation to New South Wales. Basingstoke, Hampshire: Palgrave, 2001.

Reid, Richard. Farewell My Children: Irish Assisted Emigration to Australia, 1848-70. Sydney: Anchor Books Australia, 2011.

. "There is no person starving here': Australia and the Great Famine". The Famine Irish: Emigration and the Great Hunger. Ed. Ciarán Reilly. Dublin: The History Press Ireland, 2016. 168-180.

Richards, Eric. Destination Australia: Migration to Australia since 1901. Manchester: Manchester University Press, 2009.

Rushen, Liz. Colonial Duchesses: The Migration of Irish Women to New South Wales before the Great Famine. Sydney: Anchor Books Australia, 2014.

Santamaria, B.A. Daniel Mannix: The Quality of Leadership. Melbourne: University of Melbourne Press, 1984.

Warhurst, John. "Catholics in Australian Politics since 1950". The Encyclopedia of Religion in Australia. Ed. James Jupp. Cambridge: Cambridge University Press, 2009. 261-266. 
Wooding, Jonathan M. "“A native style springing from a people possessed of original power and mind': The Irish Round Tower in Australian Architecture". Australasian Journal of Irish Studies 17 (2017): 59-79.

\section{Websites Cited}

ADB: Australian Dictionary of Biography: <adb.anu.edu.au>

Anchor Books Australia: <anchorbooksaustralia.com.au>

Bloomsday in Melbourne: <bloomsdayinmelbourne.org.au>

"Not Just Ned: A True History of the Irish in Australia", National Museum of Australia, Canberra: 〈nma.gov.au>

Irish Famine Memorial, Sydney: <irishfaminememorial.org>

Irish Language Association of Australia: <gaeilgesanastrail.com>

Irish Studies Association of Australia and New Zealand: <isaanz.org>

Elizabeth Malcolm, FRHistS, FASSA, is an Honorary Professorial Fellow at the University of Melbourne, having previously held the Gerry Higgins Chair of Irish Studies during 20002012. She studied under Professor Patrick O'Farrell in Sydney, before taking her PhD degree from Trinity College, Dublin. She worked in Irish Studies Institutes in Belfast and Liverpool and has published widely on Irish social and cultural history. Her books include: 'Ireland Sober, Ireland Free': Drink and Temperance in Nineteenth-Century Ireland (1986); Medicine, Disease and the State in Ireland, 1650-1940 (1999), edited with Professor Greta Jones; and The Irish Policeman: A Life, 1822-1922 (2006). Her latest book, A New History of the Irish in Australia, written with Associate Professor Dianne Hall, was published in Sydney in late 2018. She served during 2006-2012 as the first President of the Irish Studies Association of Australia and New Zealand (ISAANZ).

e.malcolm@unimelb.edu.au 